\title{
THE IMPACT OF FINANCING AND SECURITISATION ON REAL ESTATE MARKETS AND URBAN DEVELOPMENT IN SINGAPORE
}

\author{
ONG SEOW ENG and SIM LOO LEE \\ National University of Singapore
}

\begin{abstract}
The real estate market can be characterised into the space market for usage, the asset market for investment, and the development industry providing the real estate stock. Urban development and growth is spatially and intrinsically linked to the development industry. However, little theoretical and empirical work exists to link changes in the space and asset markets to urban development. In this respect, an interesting phenomenon in recent years in Asia is the increasing popularity in the securitisation of real estate. The securitisation of real estate in Singapore, in particular, has been introduced as a means to promote and further develop Singapore as a global financial centre. This paper appeals to the DiPasquale \& Wheaton theoretical construct to examine the impact of Singapore's space and asset markets on urban development.
\end{abstract}

Keywords: Financing, securitisation, real estate markets, urban development, Singapore.

\section{INTRODUCTION}

Singapore, an island city-state with a land area of $648 \mathrm{sq} \mathrm{km}$ and a resident population of 3.9 million, has a population density of approximately 6,000 persons per sq km; a density which is one of the highest in the world. The island, which faces a severe constraint of land scarcity, had a total built-up area of about $330 \mathrm{sq}$ $\mathrm{km}$ in 2000, slightly more than half of its total land area. Despite its physical constraint of land scarcity, Singapore has progressed rapidly from a developing economy with per capita GNP of US\$800 in 1965 to a newly industrialised economy with an estimated per capita GNP of US\$32,940 in 1997, the fourth highest in the world (World Bank, 1998). It was recently ranked third for economic development (World Competitiveness Yearbook, 2000).

Many studies on Singapore have shown that from an under-developed economic base in 1965, Singapore has made strong economic progress and to-date, has an impressive infrastructure in terms of housing, commerce and telecommunications (Teo \& Kong, 1997; Doling, 1999; Chua, 2000). 
From 1960, when the Housing and Development Board (HDB) was established to the present, it has built 924,488 public housing flats (Ministry of Information, Communications and the Arts). Out of these, 82 per cent were sold under the Home Ownership Scheme. In addition to the public housing flats, about 195,913 private residential units were constructed, making a total of approximately 1.1 million dwelling units. With a well-developed transport, logistics and telecommunication infrastructure, Singapore has been cited as the most developed example of integrated services delivery in the world (US Intergovernmental Advisory Board, 1999). In 1999, it won the Intelligent City of the Year award (World Teleport Association). The path to such a "success story" makes for an interesting case study in urban development.

Studies have shown that urban development and growth is spatially and intrinsically linked to the real estate development industry, which is influenced greatly by financing policies (Fujita, 2000; Mera \& Renaud, 2000; Phang, 2001). Viewed in a larger context, the real estate market can be characterised into the space market for usage, the asset market for investment, and the development industry providing the real estate stock. This paper focuses on the linkages in the changes in the space and asset markets to urban development in the spirit of Fisher (1992). In particular, this paper examines the critical role of financing policies on the real estate market and urban development of Singapore.

Three examples are used to illustrate how changes in financing policies affected prices, and consequently construction and development in Singapore. Finally, this paper examines how the securitisation of real estate in the capital markets affects the asset market for investment, and ultimately the development industry.

Section 2 provides the theoretical construct for real estate assets and space, while section 3 examines the role of financing in urban development in Singapore. Section 4 introduces the real estate securitisation experience in Singapore and section 5 evaluates the implications of the introduction of real estate derivative instruments on Singapore's urban development strategy and economic development over the longer term.

\section{THEORETICAL CONSTRUCT}

The DiPasquale and Wheaton (1992) conceptual framework for real estate assets and space is well established in urban economics literature. The "Four Quadrant" graph in Figure 1 depicts the "long run" relationships and linkages between and within space and asset markets. 


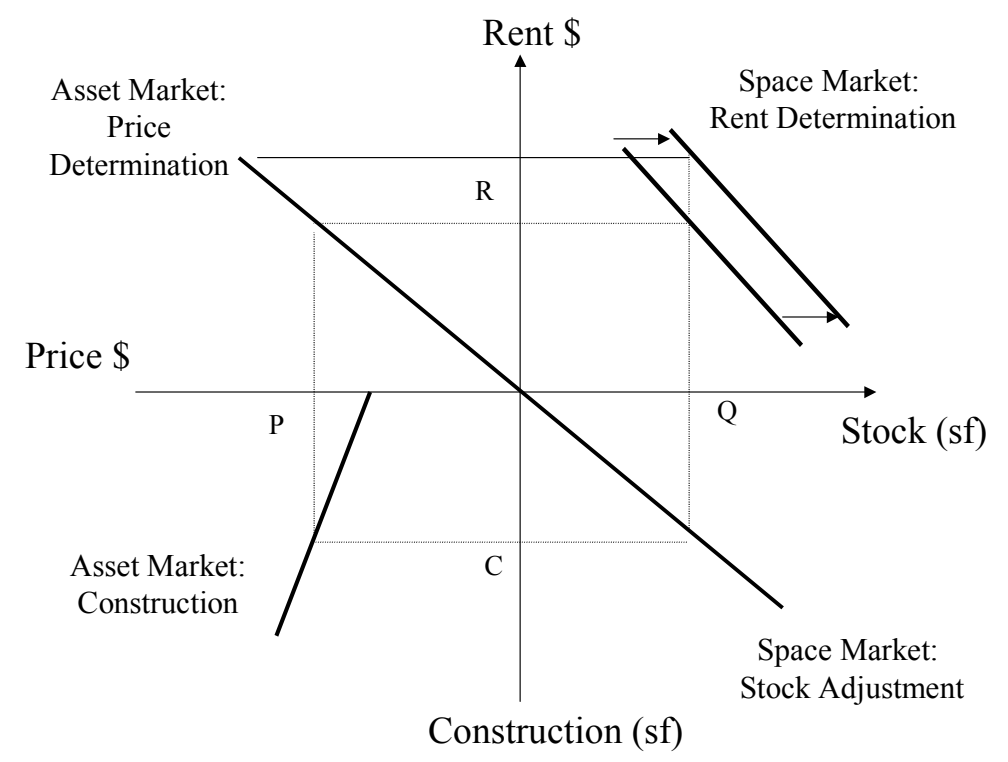

The northeast quadrant examines the determination of rent in the space market, the northwest quadrant shows the asset market valuation process, relating the equilibrium property price to the level of current rental. The southwest quadrant depicts the operation of the development industry and physical asset production process. Here, property prices drive the amount of construction activity (including rehabilitation and redevelopment as well as new development). The higher the property price, the more construction activity would take place. The southeast quadrant completes the integration of the space and asset markets by linking the rate of construction to the total stock of built space. The four quadrants depict a long run "steady state" equilibrium.

The framework is important to understand the linkages between asset markets and urban development. The central theme in this paper is that policy changes in the asset markets, be they financing, price controls, rent subsidies, etc, affect urban development. In the following section, we will examine three examples to illustrate how changes in financing policies affected prices and consequently construction and development in Singapore. 


\section{THE ROLE OF FINANCE IN URBAN DEVELOPMENT IN SINGAPORE}

A great deal of research has been done on various aspects of housing in Singapore (Chua, 1997, 2000; Phang, 2001; Sim et al, 1993; Tan, 1998; Teo \& Kong, 1997). This section, however, focuses on the role of financing in promoting Singapore's housing development and its impact on urban development. It discusses how financing through the $\mathrm{CPF}$ and mortgage loans affect the public and private housing markets and urban development. As Sim et al (1993) observe, housing development is very much an integral part of the development of Singapore.

\section{Housing development}

When Singapore gained independence in 1965, the government owned $44 \%$ of the total land area (Sim et al, 1993). Much of the country was undeveloped and the urban living conditions were primitive (Kaye, 1960). The government recognised that housing development was an integral part of an overall plan for urban development and ultimately, national development (Sim et al, 1993). The Housing and Development Board (HDB) was set up as a statutory board to undertake a housing program for Singapore. The HDB's top priority was to build as many housing units as possible within a short time. Four decades after the first HDB housing program was launched, the HDB has built more than 924,488 flats, which house about $86 \%$ of Singapore's population (Ministry of Information, Communications and the Arts). The housing program was not seen merely as creation of housing, but rather that the occupiers would become owners. This is viewed as providing households a stake in the country (Ooi, 1994).

\section{Financing as the key}

The key to the success of the housing program in Singapore is the Central Provident Fund (CPF) scheme. The CPF scheme is a mandatory savings program where both the employer and employee make monthly contributions. The contributions are based on a percentage of the employee's monthly gross salary. CPF annual contributions have grown from S\$47 million in 1965 to $\mathrm{S} \$ 14,132.9$ million in $2000(\mathrm{~S} \$ 1.78=\mathrm{US} \$ 1)$. CPF balance rose from $\mathrm{S} \$ 359$ million to $\mathrm{S} \$ 90$ billion over the same period (Figure 2).

The CPF Board was set up on 1 July 1955, not long after Singapore gained independence from the Commonwealth. As a statutory board, the main task for $\mathrm{CPF}$ is to implement a savings scheme to provide retirement benefits. CPF became a national compulsory savings fund, where both employers and employees contribute a portion of the employee's income to CPF. All funds paid into an employee's CPF are channelled into three accounts - the Ordinary, Special and 
Medisave accounts. Of these, CPF funds in the Ordinary Account can be used for housing, shares and other approved investment schemes.

\section{Figure 2: CPF contributions, withdrawals and balance}

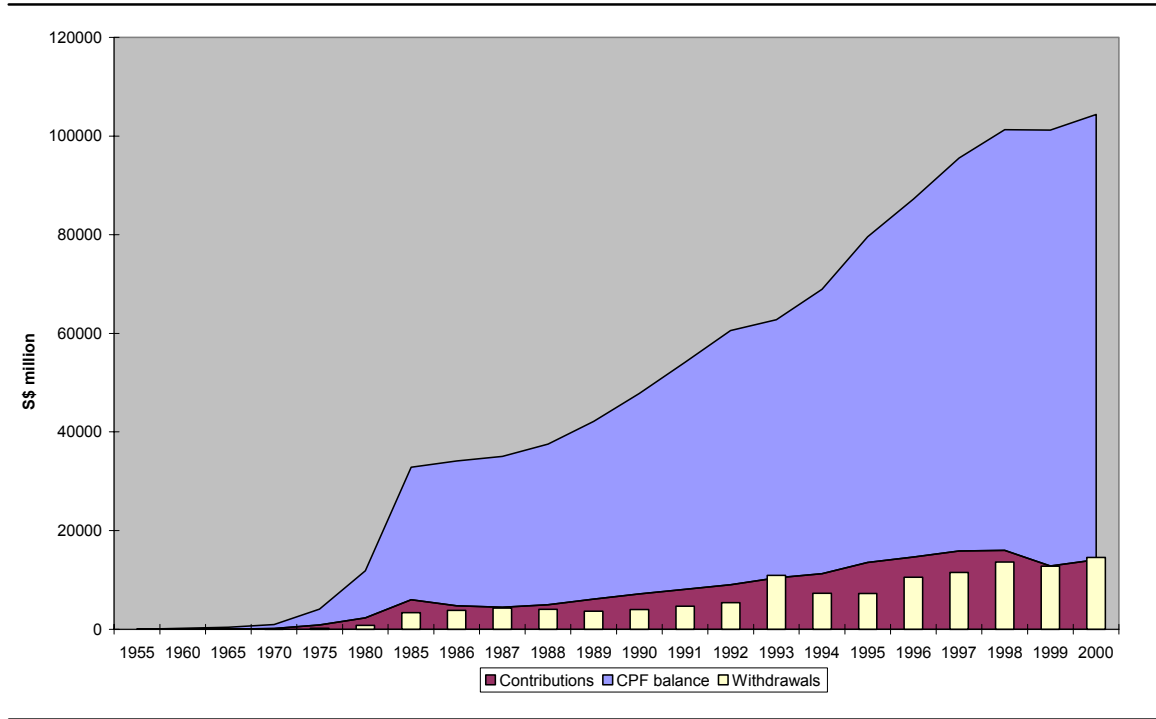

Utilisation of CPF for housing is explicitly provided under the Home Ownership Scheme (HOS), launched in 1968 to boost home ownership. Essentially, CPF savings can be used to purchase HDB flats (1968), private residential properties (1981), non-residential properties (1986). The main idea behind allowing CPF savings to be used for the purchase of residential properties is to boost home ownership and for investment. Any CPF contributor may withdraw in lump sum or monthly amounts to pay for housing. Currently, only residential properties in Singapore, and only freehold or leasehold of at least 60 years are eligible. The success of this scheme can be seen in the increase from home ownership rate from $29 \%$ in 1970 to $90 \%$ in 2001 .

CPF plays two critical roles. First, CPF funds are channelled into the public sector at low interest costs to support the public housing program (Doling, 1999). Second, purchasers of HDB flats can use their CPF contributions for both the down payment and loan repayments (Tan, 1993). In other words, the high ownership rate in Singapore was made possible by making available a cheap source of finance for construction, as well as for owners to utilise their compulsory savings to enhance affordability. 
The impact of CPF on the real estate market is immense, considering the sheer size of CPF balances. As at September 2001, the average balance per member amounts to $\$ \$ 31,200$ (Figure 3). The effect of allowing CPF to be used for residential properties can be seen not only in the high ownership of HDB flats $(86 \%)$, but also in the number of building units over the past three decades. This is shown in Figure 4.

Figure 3: Average CPF balance per member

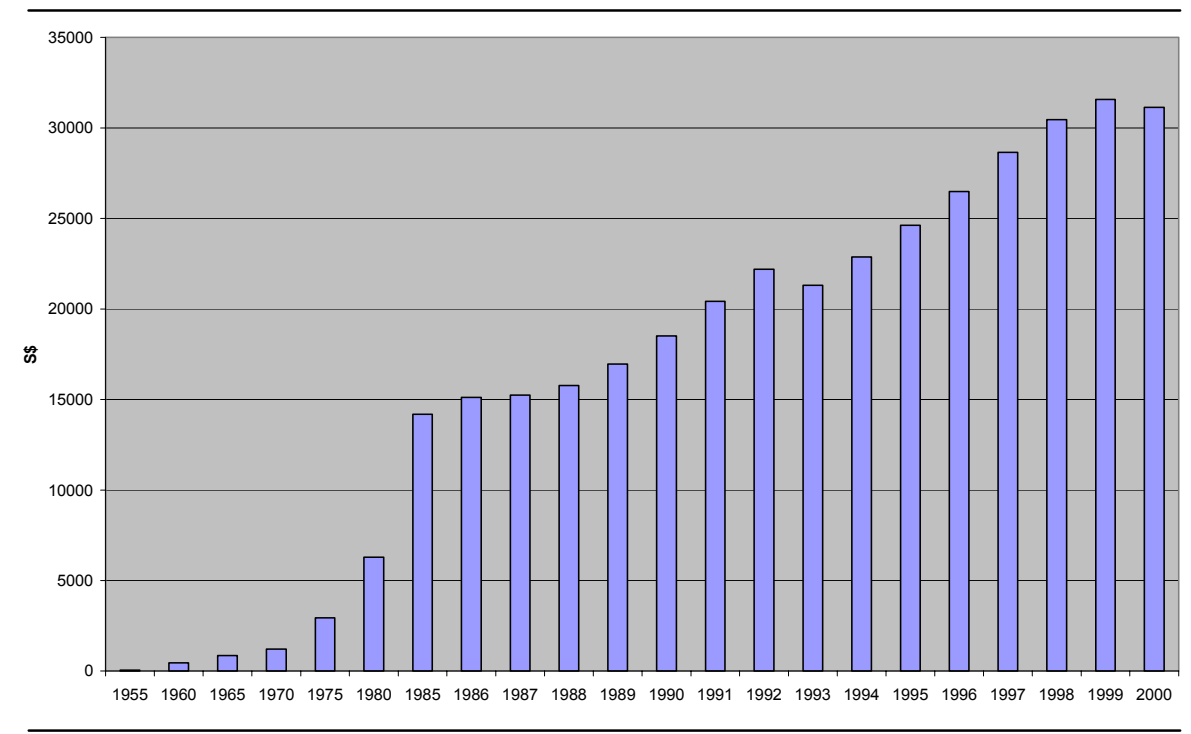

Two other examples will be cited to illustrate the role of financing in urban development.

\section{Mortgage financing}

Owners of HDB flats may sell their units in the open secondary market after a bar of five years (Ong and Koh, 2000). Up until 1989, the HDB imposed a mortgage ceiling for the prices of resale HDB flats. This effectively imposed a ceiling on the prices of resale HDB flats since rising flat prices meant higher cash outlays beyond the restricted mortgage loan. In the early 1990s, HDB lifted the mortgage ceiling. The reason was to relieve purchasers of the increased financial burden (Chua, 2000) and partly because of the slowdown in completion of the HDB program. From 1992, purchasers are able to obtain mortgages based on the market valuation of the flats.

The HDB resale price index measures the performance of the public housing from 1990. The effect of changing the mortgage ceiling is a dramatic increase in the 
prices of resale flats, as seen in Figure 5. The effect on development (completion of public flats) is only witnessed subsequently in the mid-1990s (see Figure 6). This lagged adjustment effect is consistent with the DiPasquale and Wheaton construct, where stock adjustment takes place in the southwest quadrant.

\section{Figure 4: Building statistics (total units built)}

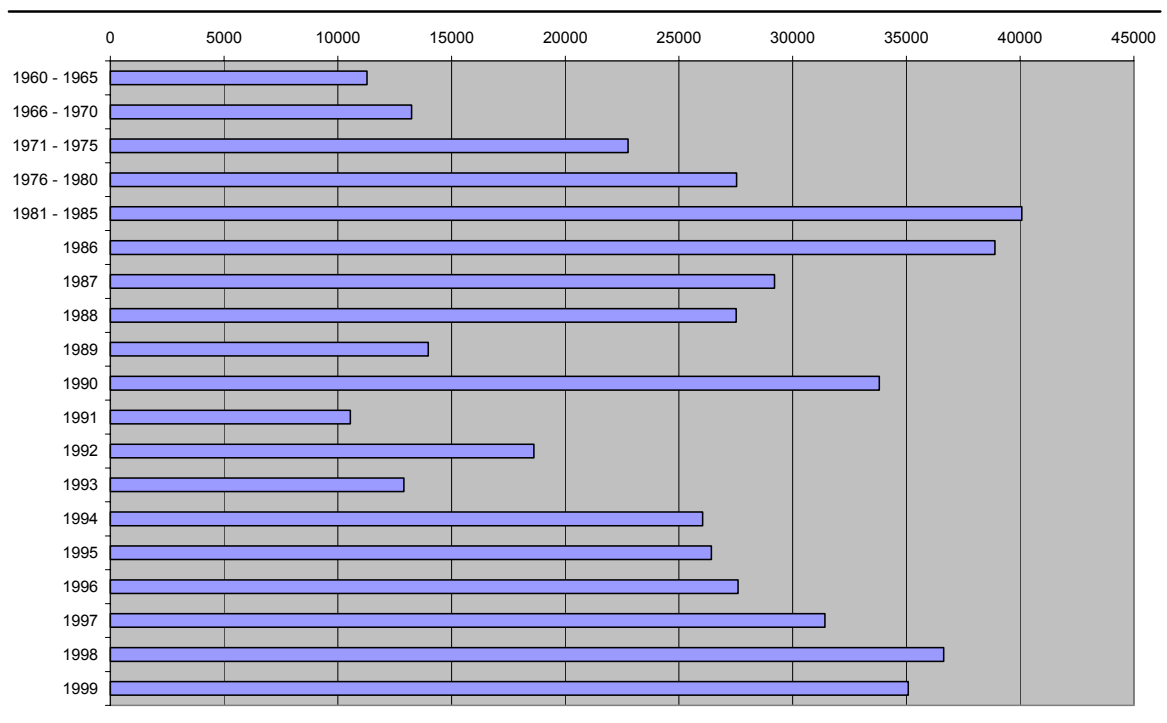

Figure 5: HDB resale price index

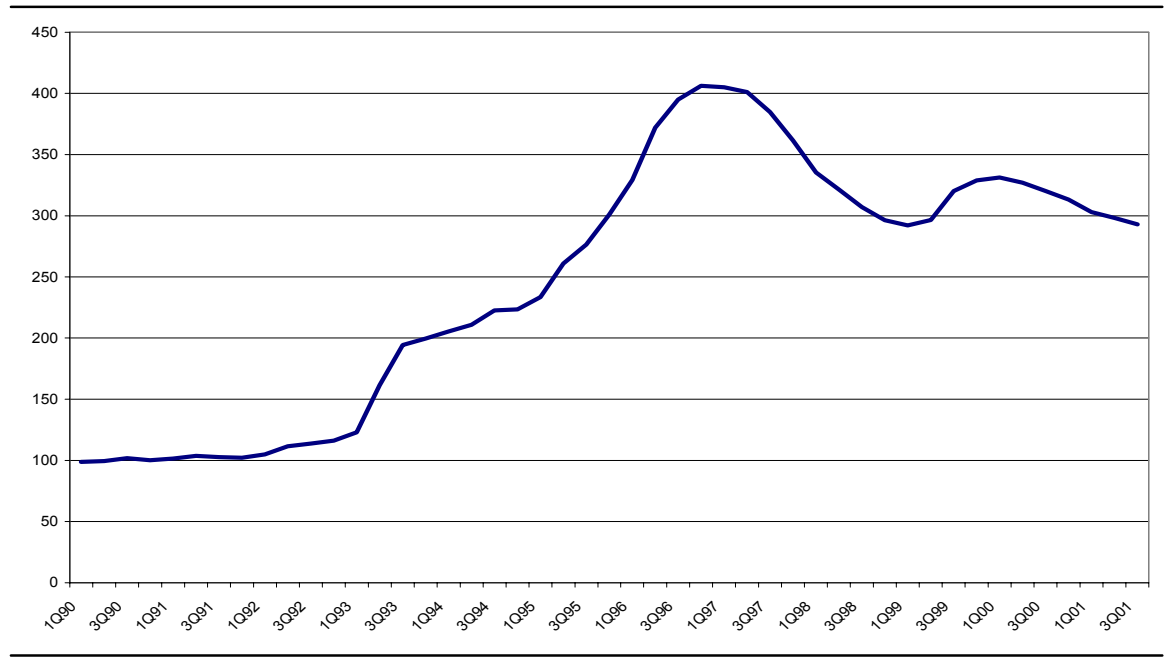




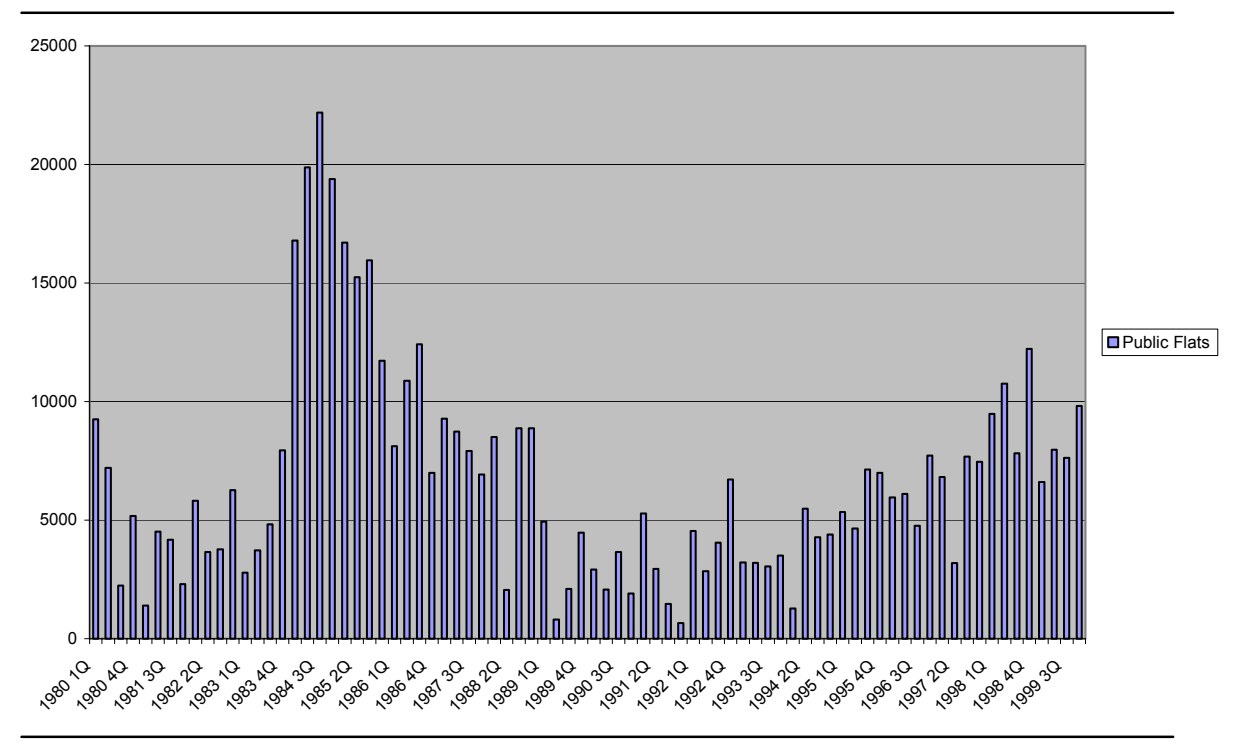

\section{Limits on loans for private property}

Before 1996, the Monetary Authority of Singapore (MAS), the de-facto central bank of Singapore, mandated that the loan and CPF utilization (in lump sum for down payment) for private property purchase should be no more than $90 \%$ of the valuation or purchase price, whichever is the lower. The $90 \%$ guideline is also referred to as quantum. The implication is that $10 \%$ of the property price must be in cash or equity.

However, speculation in the private property market from 1993 became a cause for concern. In May 1996, the quantum was reduced to $80 \%$. The main implication is that cash outlay is increased from $10 \%$ to $20 \%$. Other measures to curb speculation included the limit of only one Singapore dollar loan to permanent residents for property purchase and the taxation of gains from short-term transactions (less than 3 year holding period) in residential property. Figure 7 shows the effect of this tightening in financing policy; property prices declined sharply over 1996 through 1998. Although the decline in prices was aggravated by the Asian economic crisis in 1997, the effect is nonetheless apparent - financing policy does affect property prices.

The effect on the supply of private residential units is significant. As Figures 8 and 9 show, the take-up rate for new developments decreased sharply from about $100 \%$ to as low as $9 \%$ in 1998 . The actual supply or completion continued to rise 
from 1996 through 1997, but new supply fell subsequently in 1998. Many projects grounded to a halt or were delayed.

\section{Figure 7: Private property price index}

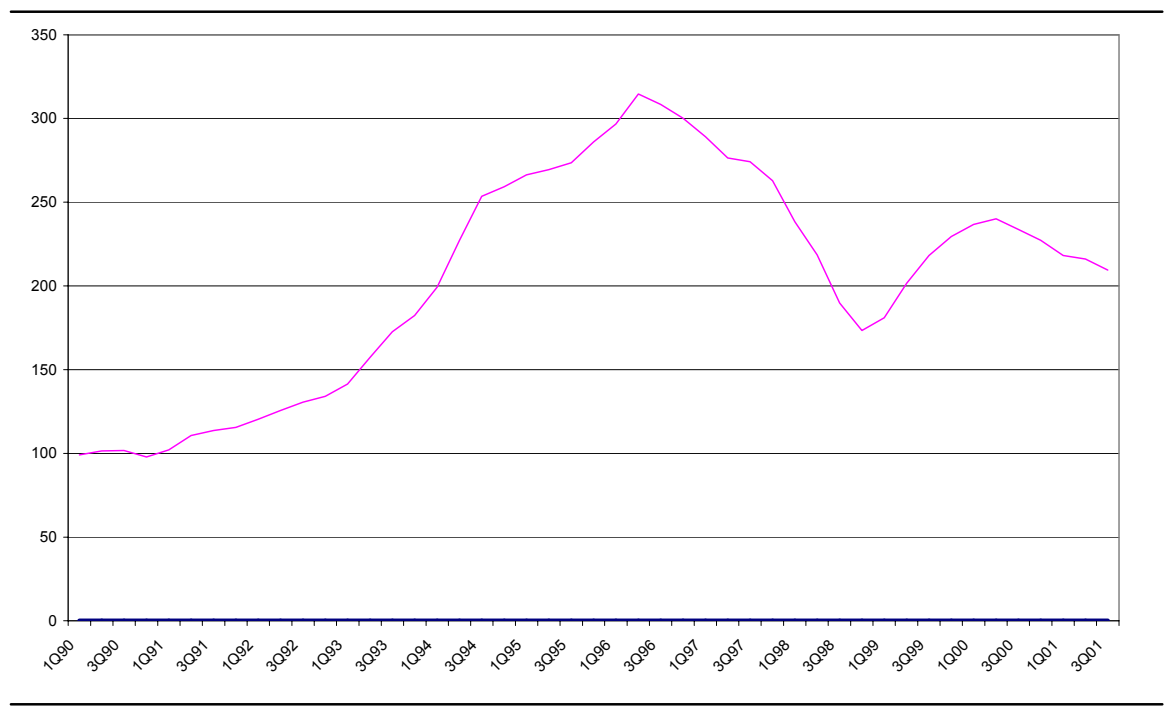

Figure 8: Private units completed

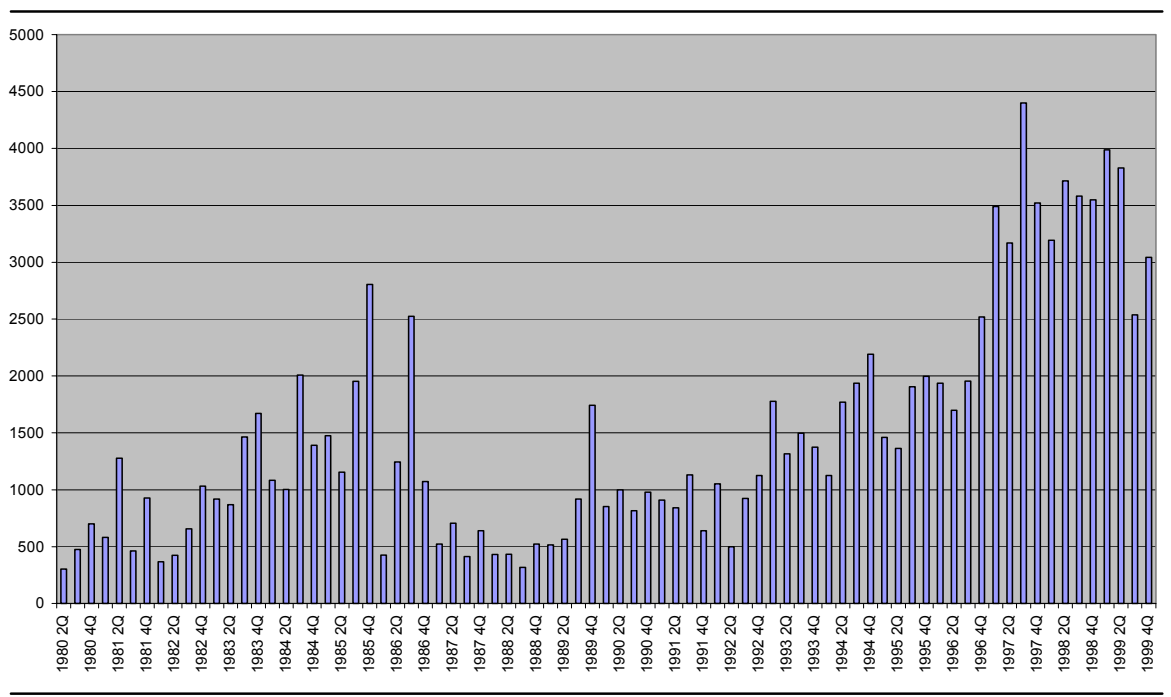

Pacific Rim Property Research Journal, Vol 9 No 3 
The above examples are used to illustrate how financing policy changes affect the property price, and consequently, the effect on urban development.

\section{FINANCIAL LIBERALISATION}

In July 1998, the Monetary Authority of Singapore (MAS) formulated a series of strategic plans to enhance the development of the capital market; in particular, the bond market. The following year witnessed the launch of a series of medium term bonds (up to seven years in maturity) issued by quasi-government agencies. MAS also recommended the securitisation of real estate to increase the depth and diversity of Singapore's debt markets (Wong, 1998; Lee and Ang, 1998).

\section{Asset securitisation}

Asset backed securitisation in the Singapore context refers to a contractual arrangement, whereby real estate owners sell their real estate asset(s) to a special purpose vehicle that issues debt instruments to finance the purchase. The debt instruments are backed by cash flows generated from the real estate asset(s). The legal transfer or separation of the asset to a special purpose vehicle (SPV) is the key feature that distinguishes a securitisation arrangement from the traditional mortgage-backed or collateralised bond issues.

\section{Figure 9: Take-up rates}

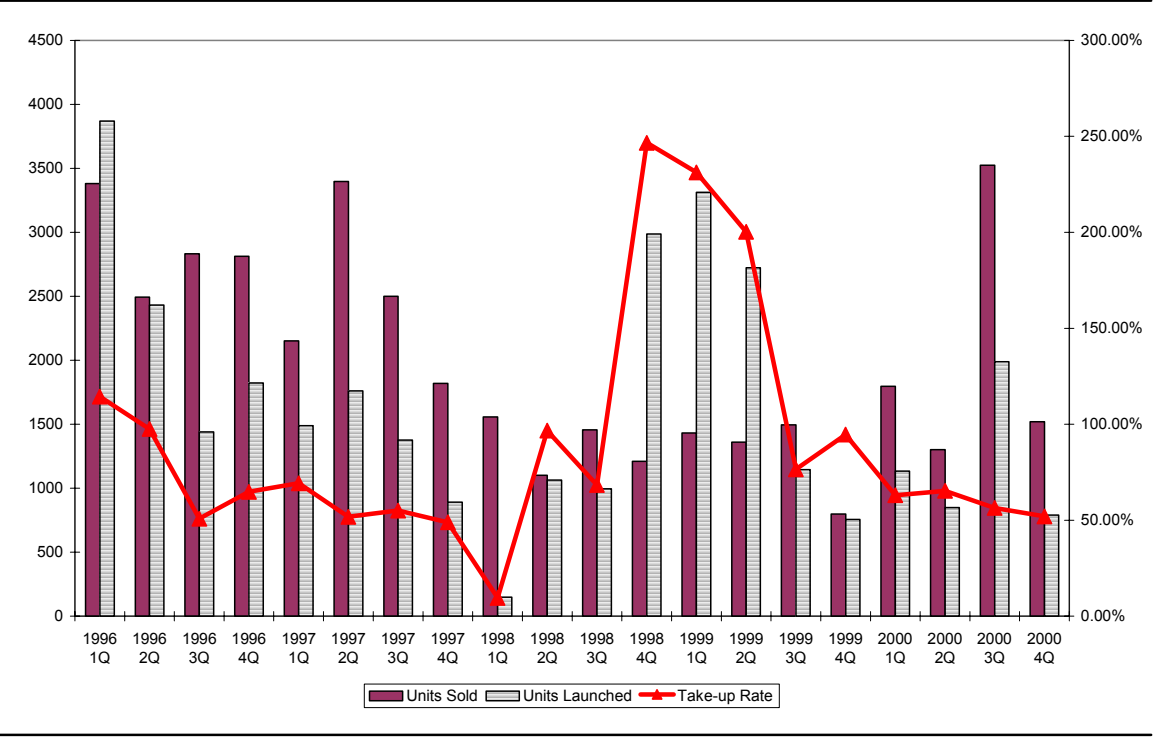

Securitisation has been a distinctive feature of the financial system in the USA (Pryke et al, 1994), but its development has been slow in other countries. 
According to OECD (1995), the best prospects in Europe appear to be in Finland, France, Spain and Sweden. Both Finland and Sweden have raised funds for social housing through securitisation (Tulla, 1999). In Asia, Hong Kong started in 1994, while Japan and Korea introduced it after the Asian financial crisis in 1997. As in many other countries, securitisation is a recent phenomenon in Singapore.

Table 1: Securitisation deals in Singapore

\begin{tabular}{|c|c|c|c|c|c|}
\hline & $\begin{array}{c}\text { Neptune } \\
\text { Orient Line } \\
\text { HQ }\end{array}$ & $\begin{array}{c}\text { Robinson } \\
\text { Point }\end{array}$ & $\begin{array}{c}\text { The } \\
\text { Clearwater }\end{array}$ & $\begin{array}{c}\text { Century } \\
\text { Square } \\
\text { Shopping } \\
\text { Mall } \\
\end{array}$ & $\begin{array}{l}268 \text { Orchard } \\
\text { Road }\end{array}$ \\
\hline Location & $\begin{array}{c}\text { Alexander } \\
\text { Road }\end{array}$ & $\begin{array}{c}\text { Shenton } \\
\text { Way }\end{array}$ & $\begin{array}{c}\text { Bedok } \\
\text { Reservoir }\end{array}$ & Tampines & $\begin{array}{c}\text { Orchard } \\
\text { Road }\end{array}$ \\
\hline $\begin{array}{c}\text { Property } \\
\text { type }\end{array}$ & Office & Office & Residential & $\begin{array}{c}\text { Shopping } \\
\text { Centre }\end{array}$ & Office \\
\hline Owner & NOL & $\begin{array}{l}\text { Birchvest } \\
\text { Investment } \\
\text { Pte Ltd. } \\
\text { (DBS } \\
\text { Land) }\end{array}$ & Pidemco Land & $\begin{array}{l}\text { First Capital } \\
\text { Corporation }\end{array}$ & $\begin{array}{l}\text { RE Properties } \\
\text { (DBS Land) }\end{array}$ \\
\hline $\begin{array}{l}\text { Net floor } \\
\text { area (sqf) }\end{array}$ & 217,153 & 132,869 & $\begin{array}{c}295,318 \text { (land } \\
\text { area) }\end{array}$ & $197,055^{\#}$ & 132,111 \\
\hline $\begin{array}{l}\text { Market } \\
\text { Value of } \\
\text { Property }\end{array}$ & $\$ 185$ million & $\begin{array}{l}\$ 193 \\
\text { million }\end{array}$ & $\begin{array}{l}\text { Land value: } \\
\$ 160 \text { million } \\
\text { (\$54 psf of } \\
\text { land price) }\end{array}$ & $\$ 200$ million & $\begin{array}{l}\$ 172 \text { million } \\
+\$ 12 \text { million } \\
\quad(\text { cash })\end{array}$ \\
\hline $\begin{array}{c}\text { Unit Price } \\
\text { (\$psf) }\end{array}$ & $\$ 851$ & $\$ 1,450$ & $\begin{array}{c}\$ 460 \text { (average } \\
\text { sale price) }\end{array}$ & $\$ 1,015$ & $\$ 1,392$ \\
\hline $\begin{array}{l}\text { Special } \\
\text { Purpose } \\
\text { Vehicle } \\
\end{array}$ & $\begin{array}{c}\text { Chenab } \\
\text { Investments } \\
\text { Ltd }\end{array}$ & $\begin{array}{l}\text { Visor } \\
\text { Limited }\end{array}$ & $\begin{array}{c}\text { Silverlac } \\
\text { Investment } \\
\text { Ltd }\end{array}$ & N.A. & $\begin{array}{l}\text { Baronet } \\
\text { Limited }\end{array}$ \\
\hline Underwriter & DBS Bank & DBS Bank & $\begin{array}{c}\text { Tokyo- } \\
\text { Mitsubishi } \\
\text { International } \\
\text { (Singapore) } \\
\text { Ltd }\end{array}$ & DBS Bank & DBS Bank \\
\hline $\begin{array}{c}\text { Value of } \\
\text { bond issued }\end{array}$ & $\$ 185$ million & $\begin{array}{l}\$ 193 \\
\text { million }\end{array}$ & $\$ 100$ million* & $\$ 200$ million & $\$ 184$ million \\
\hline $\begin{array}{l}\text { Type of } \\
\text { security }\end{array}$ & $\begin{array}{c}\text { Fixed rate } \\
\text { mortgage } \\
\text { backed } \\
\text { bonds }\end{array}$ & $\begin{array}{c}\text { Fixed rate } \\
\text { secured } \\
\text { bonds }\end{array}$ & $\begin{array}{l}\text { Fixed rate } \\
\text { bonds }\end{array}$ & $\begin{array}{l}\text { Fixed rate } \\
\text { bonds }\end{array}$ & $\begin{array}{c}\text { Fixed rate } \\
\text { secured } \\
\text { bonds }\end{array}$ \\
\hline $\begin{array}{l}\text { Bond Yield } \\
\text { coupon rate }\end{array}$ & $\begin{array}{l}6.75 \% \\
7.25 \%\end{array}$ & $\begin{array}{l}6 \% \\
2 \%\end{array}$ & $4.75 \%$ & N.A. & $\begin{array}{l}5.5 \% \\
6.5 \%\end{array}$ \\
\hline Bond Tenure & 10 year & 10 year & 3 year & 7 year & 10 year \\
\hline Issue date & March 1999 & $\begin{array}{c}22 \text { July } \\
1999 \\
\end{array}$ & 30 July 1999 & June 1999 & $\begin{array}{c}\text { 1 September } \\
1999 \\
\end{array}$ \\
\hline \multicolumn{6}{|c|}{$\begin{array}{l}\text { * The bonds are securities by receivables or sales proceeds from the Clearwater Condominium project, } \\
\text { which was still under construction at the date of issuing of the bond. } \\
\text { Century Square has a total lettable area of } 217,759 \text { sqf, of which } 197,055 \text { sqf of the shopping mall were } \\
\text { under the ownership and securities by the First Capital Corporation. }\end{array}$} \\
\hline
\end{tabular}


The first asset securitisation deal, defined more narrowly, in Singapore involves the sale of the Neptune Orient Lines (NOL) office building. The transaction of the 26-storey building valued at S\$185 million as of December 1998 was funded by 10 -year fixed rate mortgage-backed bonds via a special purpose vehicle, Chenab Investments Ltd. Six other securitisation deals were further undertaken in 1999 involving a total of S\$1,842 million. The details of the securitisation transactions are summarized in Table 1. All the sellers/owners of the asset securitisation deals are major property developers.

Two features of these asset backed securitisation deals are invariably distinctive and unique to Singapore. First, there is an explicit option in the securitisation agreement that entitles the asset backed bond originator to lease back the property wholly or partially from the special purpose vehicle for a period not longer than the bond maturity. In return for the lease, the originator will guarantee and pay the special purpose vehicle rentals and other income, which will be equivalent to or exceed its interest obligations under the bonds.

Secondly, the securitisation agreements incorporate explicit call options that allow the bond originator to claim on the capital appreciation in the property. The call option is of an American type, exercisable anytime within a pre-specified period, say from the fourth year after the issuing date to the sixth month before the expiration of the bond. The call option gives the bond originator the right to buyback the building at a discount to the prevailing market valuation, but at no less than the original purchase price.

\section{PROPERTY FUNDS}

In May 1999, MAS released its guidelines on the regulation of property funds, in response to the Stock Exchange of Singapore Review Committee's recommendation to set up property funds, so as to broaden the range of products that investors could trade in. The concept of property funds is similar to that of Real Estate Investment Trusts (REITs) in the U.S. and property trusts in Australia. The guidelines require that at least $70 \%$ of the total assets of the property fund have to be invested in real estate or property-related assets. Out of this $70 \%$, at least half must be in real estate, be it freehold, leasehold or joint owner of properties. Property-related assets include securities of property companies, mortgage-backed securities and other property funds.

Perhaps the most significant guideline is that there are no tax incentives for property funds in Singapore. Property funds will be taxed at the corporate level and the tax paid can be passed on as a tax credit to shareholders when income is distributed. MAS clarified that the objective was merely to broaden the range of 
financial products and not to promote property funds over other investment forms by providing tax and other incentives.

In contrast, profits made by a REIT in the US are tax-free if the fund distributes $90 \%$ of the profits to its unit holder. Australian property trusts also enjoy tax incentives, but property trusts in Malaysia do not. Another difference is that the regulation in the US provides that a REIT must have at least $75 \%$ of its assets in real estate.

The Property Fund cannot be involved in property development, whether on its own or in a joint venture or by investing in unlisted property development firms. As explained by the MAS, this is because property development carries a higher risk and also due to the fact that property funds are a new type of collective investment scheme in Singapore. However, MAS is prepared to review the guidelines after the investing public becomes more familiar with the scheme. In addition, the restriction on property development activities should not hinder the ability of fund managers to manage and invest the property fund.

Real estate could be held through direct ownership of property located in or out of Singapore or through shares in an unlisted property investment company. Real estate related assets could be debt securities, listed shares of property companies, mortgage backed securities, other property funds and incidental assets. The other remaining portion of investments includes government / statutory board securities, debt securities and shares in non-property companies, cash and near cash items.

The guidelines also state that the fund cannot invest in vacant land, except in property to be built on approved vacant land. Investments in uncompleted nonresidential property are restricted to not more than $10 \%$ in Singapore or uncompleted property development outside of Singapore. The fund also cannot invest more than $5 \%$ in uncompleted property development of a single developer. Another restriction is that it cannot invest more than $5 \%$ in anyone issuer's securities or any one manager's fund. A company and its subsidiary companies are regarded as one issuer or manager.

The initial reaction by the market was less than euphoric, in part due to the lack of tax incentives, but more because of the issue of rental yields. For property funds to be attractive, the dividend yield must be sufficiently high, and this is largely a function of rental yields. To-date, two property funds have been launched by Capitaland, Singapore's biggest real estate developer, and Ascendas, an international industrial property investor. Interest in property funds has been increasing, with the arrival of new players (such as Lend Lease) and mergers and acquisitions. A few more property funds are in the pipeline. 
For more details about the securitisation experience in Singapore, see Ong et al (2000).

\section{IMPLICATIONS FOR URBAN DEVELOPMENT}

The securitisation of real estate assets took place when the office property market was faced with rising vacancy rates, buffeted by weak economic growth as a result of the Asian economic crisis (Figure 10). Office prices at that time were trending downwards (Figure 11) and interest rates rose because of the currency turmoil. At that time, many developers viewed asset-backed securitisation as a good alternative to outright disposal, as they can retain the upside to any capital appreciation since the asset securitisation deal incorporates a buy-back option.

Figure 10: Office supply, new construction and vacancy rates

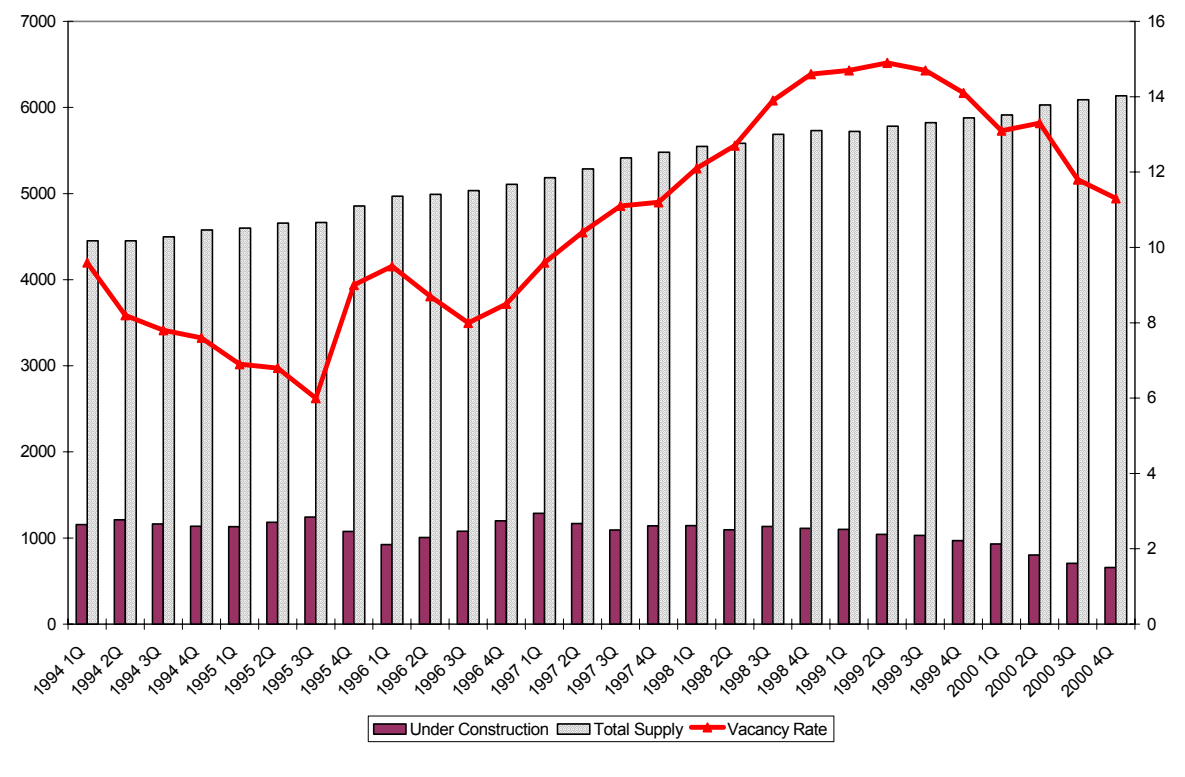

To the extent that asset securitisation affects the financing of office properties, some implications can be drawn.

Firstly, by scrutinising the assets, owners are able to reduce their leverage ratios and reduce the debt burden on their balance sheet. This would immediately reduce their interest costs. Secondly, as Figure 11 shows, prices of offices have picked up since 1999. This means that the seller of the securitised office buildings now hold a valuable call option (to buy back the property). So owners reduce their debt 
burden without sacrificing the upside price potential of their assets. Thirdly, an examination of the future / potential supply of office space (Figure 12) shows that the real estate space market is adjusting for the higher price and lower vacancy rate, in that future supply (in 2003 and 2004) is likely to increase. It is not possible to entirely attribute the increased development activity to asset securitisation given that the office space market is influenced by economic factors as much as financing factors. However, by restructuring their balance sheet through real estate securitisation, property owners can afford to undertake new developments and pursue other investment strategies. They are also able to do so with a more healthy financial position.

Figure 11: Office price index and prime lending rate

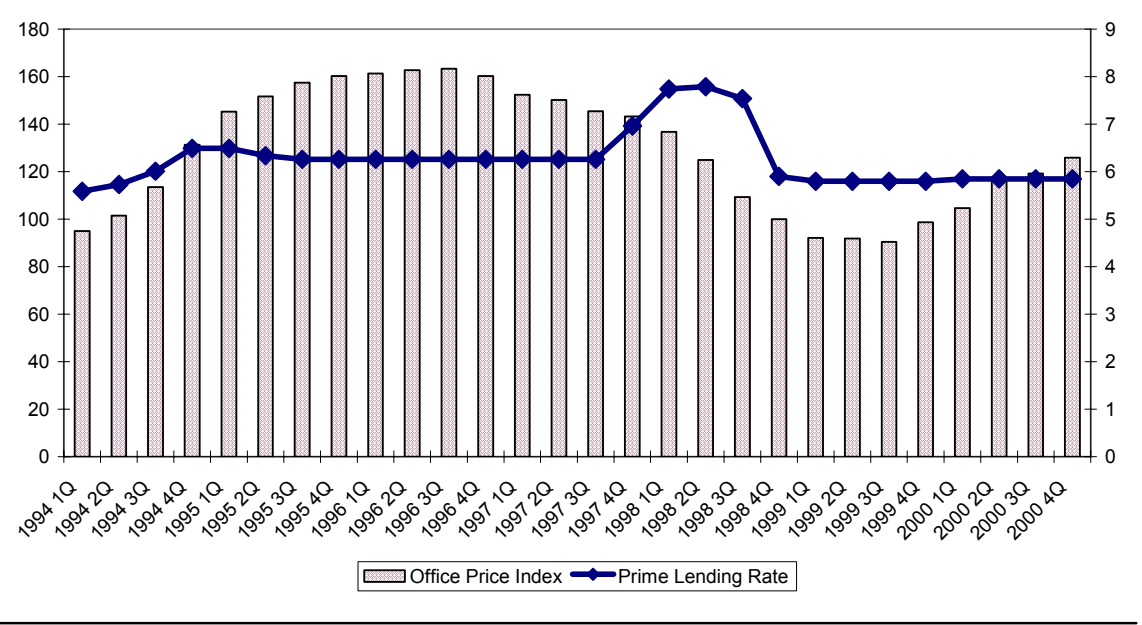

The ability to free up funds is also a benefit for property funds. In addition, small investors would be able to own and diversify in real estate, something that is traditionally not feasible given the high cost of commercial real estate.

\section{IMPLICATIONS FOR SCRUTINISING MORTGAGES}

While a secondary real estate market has developed and thrived in the United States, real estate in Singapore is essentially a primary market where real estate is held as a direct investment. As of mid-1998, only a very small portion of the outstanding real estate loans held by financial institutions is securities, primarily in the form of corporate bonds backed by real estate mortgages. 
The potential for securitisation of mortgages in Singapore is immense. The amount of outstanding real estate loans, comprising building and construction loans issued by banks and housing loans issued by finance companies, totalled S $\$ 52.6$ billion as of June 1998. This represents over 37\% of total loans granted by financial institutions in Singapore.

If and when mortgages are securities, banks would be able to increase their capacity in terms of mortgage origination. This would potentially improve the ease of financing for residential property buyers. The effect on residential prices and development could be interesting.

Figure 12: Office space planned \& under construction

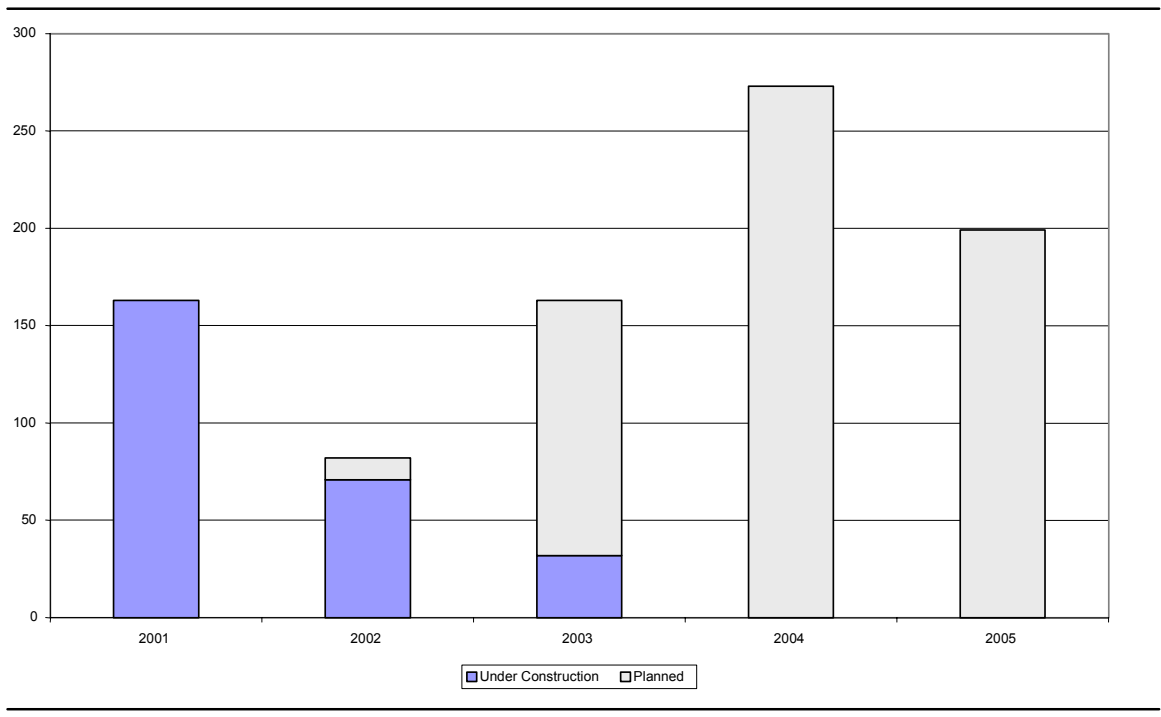

\section{Channel of transmission and global financing}

Two other implications associated with real estate securitisation are worth highlighting. First, the channel of transmission is now through institutions rather than individuals. While financing policies affect real estate prices and consequently development through individuals, securitisation affects real estate prices and development through institutions (developers and investors). As markets become more sophisticated, institutions must play a major role.

Second, real estate securitisation is a conduit for global external financing for urban development in a largely domestic real estate market. The earlier examples of financing policies involves domestic financing arrangements (CPF and bank loan), but the development of a secondary real estate market, coupled with the 
introduction of innovative financing instruments allows the real estate market to tap into the global flow of funds. This not only opens up the financing landscape considerably, but is also consistent with the MAS objective of developing Singapore as a major financial centre.

\section{CONCLUSION}

This paper views urban development in the larger context of the interaction between the asset and space markets. Changes in development activities in the space market respond to changes in the rentals and prices in the asset markets (DiPasquale and Wheaton, 1992). Several examples from Singapore are used to illustrate the linkages; in particular, the effect of mandatory savings, changes in mortgage ceiling and loan quantum. As such, an integrated approach in the study of urban development would be useful (Phang, 2001; Mera and Renaud, 2001).

The recent financial liberalisation through the creation of instruments such as asset backed securities and mortgage backed securities, is likely to affect the real estate development landscape (Ong et al, 2000). The main implication is that global investors and institutions can now finance urban development activities, which are largely domestic in nature. In this way, real estate markets can tap into the global market for funds, and avail themselves to a larger universe for financing.

Another recent measure by the MAS, in its challenge to develop Singapore as a financial center, is the regulation for financial institutions to divest all non-core assets, including property, from their portfolio. Several large financial institutions in Singapore will be affected by this new regulation, and when these institutions divest their property, it will affect real estate development. The actual impact of financial liberalisation on real estate and urban development would only be felt in subsequent years and that remains an interesting avenue for future research.

\section{REFERENCES}

Chua, B. H. (1997), Political Legitimacy and Housing Stakeholding in Singapore, London: Routledge.

Chua, B. H. (2000), Public Housing Residents as Clients of the State, Housing Studies, 15, pp. 45-60.

DiPasquale, D. and Wheaton, W. (1992) The Markets for Real Estate Assets and Space: A Conceptual Framework, Real Estate Economics, 20, pp. 181 - 198.

Doling, J. (1999), Housing Policies and the Little Tigers: How do they compare with other industrialized countries? Housing Studies, 14, pp. 229-250. 
Fisher, J. (1992), Integrating Research on Markets for Space and Capital, Real Estate Economics, 20, pp. $161-180$.

Fijuta, K. (2000), Asian Crisis, Financial Systems and Urban Development, Urban Studies, 37, pp. 2197-2216.

Lee, H.S. and Ang, W. M. (1998), MAS looking into setting up a mortgage corp., BTOnline, 21 July 1998.

Mera, K. and Renaud, B. (2001), Asia's Financial Crisis and the Role of Real Estate, London: M.E. Sharpe.

Ministry of Information, Communications and the Arts (2001), Singapore Fact Sheets Series, Singapore.

OECD (1995), Securitisation: An International Perspective, Paris: OECD.

Ong, S. E. and Koh, Y. C. (2000), Time-on-Market and Price Trade-Offs in High Rise Housing Sub-Markets, Urban Studies, 37, pp. 2057 - 2071.

Ong, S. E., Ooi, J. and Sing, T. F. (2000), Asset Securitisation in Singapore: A Tale of Three Vehicles, Real Estate Finance, 17, pp. 47 - 56.

Ooi, G. L. (1994), National identity, public housing and conservation in Singapore, Habitat International, 18, pp. $71-80$.

Phang, S.Y. (2001), Housing Policy, Wealth Formation and the Singapore Economy, Housing Studies, 16, pp. 443-459.

Sim, L.L., Lim, L. Y. and Tay, K. P. (1993), Shelter for all: Singapore's Strategy for full home ownership by the year 2000, Habitat International, 17, pp. $85-112$.

Tan, S.Y. (1998), Private Ownership of Public Housing in Singapore, Singapore: Times Academic Press.

Tan, W. (1993), Construction and economic development: the case of Singapore, Habitat International, 17, pp. 75 - 88.

Teo, S. E. and Kong, L. (1997), Public Housing in Singapore: Interpreting 'Quality' in the 1990s, Urban Studies, 34, pp. 441-452.

Tulla, S. (1999), Securitisation and Finance for Social Housing in Finland, Urban Studies, 36, pp. 647-656.

Urban Redevelopment Authority. (2001), URA Real Estate Statistics Series, Singapore. 
Wong, W. K. (1998), MAS Task Force Clearing the Way for Asset Securitization, BTOnline, 27 July. 